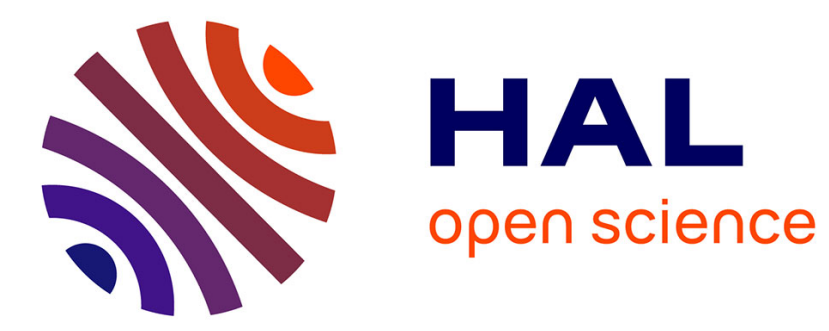

\title{
Preliminary assessment of the trophic structure of demersal fish community in the Sea of Oman
}

\author{
Laure Carassou, A.S. Al Kindi, S. Dobretsov
}

\section{To cite this version:}

Laure Carassou, A.S. Al Kindi, S. Dobretsov. Preliminary assessment of the trophic structure of demersal fish community in the Sea of Oman. Regional Studies in Marine Science, 2017, 16, pp.145151. 10.1016/j.rsma.2017.08.008 . hal-01808811

\section{HAL Id: hal-01808811 \\ https://hal.science/hal-01808811}

Submitted on 6 Jun 2018

HAL is a multi-disciplinary open access archive for the deposit and dissemination of scientific research documents, whether they are published or not. The documents may come from teaching and research institutions in France or abroad, or from public or private research centers.
L'archive ouverte pluridisciplinaire HAL, est destinée au dépôt et à la diffusion de documents scientifiques de niveau recherche, publiés ou non, émanant des établissements d'enseignement et de recherche français ou étrangers, des laboratoires publics ou privés. 
Author-produced version of the article published in Regional Studies in Marine Science, 2017, 16, 145-151 The original publication is available at http://www.sciencedirect.com/

doi : 10.1016/j.rsma.2017.08.008

Preliminary assessment of the trophic structure of demersal fish community in the Sea of Oman

Carassou L. ${ }^{1,2 *}$, Al-Kindi A.S. ${ }^{1}$, Dobrestsov S. ${ }^{1}$

${ }^{1}$ Sultan Qaboos University, College of Agricultural and Marine Sciences, Department of Marine Science and Fisheries, PO box 34, PC 123, Al-Khod, Sultanate of Oman

${ }^{2}$ National Research Institute of Science and Technology for Environment and Agriculture (Irstea), Research Unit Aquatic Ecology and Global Change (EABX), 50 avenue de Verdun Gazinet, 33612 Cestas cedex, France

* corresponding author: laure.carassou@irstea.fr

Ph: +33(0)5.57.89.26.94

Fax: +33(0)5.57.89.08.01 
Author-produced version of the article published in Regional Studies in Marine Science, 2017, 16, 145-151 The original publication is available at http://www.sciencedirect.com/

doi : 10.1016/j.rsma.2017.08.008

\section{ABSTRACT}

Detailed knowledge on the trophic ecology of marine species is an essential asset for the development of appropriate ecosystem-based management of marine fisheries. In the Sea of Oman, no studies to date have addressed the diet of demersal fish inhabiting soft-bottom habitats, despite the importance of these habitats for local fisheries. This study provides a preliminary investigation of feeding strategies displayed by demersal fish communities at two seasons in the Sea of Oman, Muscat waters, based on stomach content and dorsal muscle $\delta^{15} \mathrm{~N}, \delta^{13} \mathrm{C}$ and $\delta^{34} \mathrm{~S}$ analyses. A total of 46 fishes from 15 species, 14 families and 7 orders were collected in December 2013 and March 2014. All species displayed a carnivorous diet, with variable contributions of invertebrate and fish prey. While stomach content data suggested that Fistularia petimba (Fistulariidae), Saurida tumbil (Synodontidae) and Ulua mentalis (Carangidae) were mostly piscivorous, their $\delta^{15} \mathrm{~N}$ values strongly overlapped with other species found to feed mostly on invertebrates, suggesting a mixed fish-invertebrate feeding on a longer time scale. No significant variations were found between months in terms of mean isotopic values, but larger range values and variances were observed for $\delta^{13} \mathrm{C}$ and $\delta^{34} \mathrm{~S}$ in December, possibly indicating the consumption of food resources from more diverse mixture and origin during that month. Only $\delta^{15} \mathrm{~N}$ was weakly but significantly related to fish size at the community level, suggesting a poor size-related structuration of the demersal fish community at the spatial and temporal scale examined, consistent with other studies in the study area. However, the low number of samples analyzed limited the scope of our conclusions, and further investigations based on stable isotope methodology are needed to obtain essential biological knowledge for ecosystem-based management of fisheries in the Sea of Oman.

Keywords:

Sea of Oman; fish diet; stomach contents; stable isotopes; ecosystem-based management 
Author-produced version of the article published in Regional Studies in Marine Science, 2017, 16, 145-151 The original publication is available at http://www.sciencedirect.com/

doi : 10.1016/j.rsma.2017.08.008

\section{Introduction}

The importance of ecosystem-based approaches to fisheries research and management is now increasingly recognized on a global scale (Pauly et al., 2002; Gorospe et al., 2016). Such approaches indeed allow the incorporation of biological traits characterizing species targeted by fisheries, as well as their interactions with non-commercial species, including their prey and predators, and their environment (Starr et al., 2010; Fogarty, 2013). In particular, understanding the trophic strategies of fishes (who eats what, where and when) remains a vast working challenge for biologists. For example, when consulting the latest available inventories from Fishbase (Froese and Pauly, 2017), among the total 33,600 species recorded in the database (as for July $25^{\text {th }} 2017$ ), information on 'diet' only encompass 2,281 localized records, and information on 'food items' 8,320 records. This means a lot still needs to be done by biologists in order to fully comprehend the complexity of fish trophic strategies, essential information for management policy guidance considering the basal feeding requirements of targeted fish species within their ecosystem of interest. Information on fish diet is particularly scarce in the Arabian Gulf and Sea of Oman, despite the peculiarity of this region in terms of diversity of marine habitats, oceanographic conditions and marine biodiversity (Rastgoo and Navarro, 2017).

Among the techniques used to study fish trophic strategies, stomach contents have been traditionally employed for decades (Hyslop, 1980; Cortés, 1997). Although relatively simple to implement, stomach content analyses however present the disadvantage of providing only very recent dietary information, i.e., only prey ingested just prior fish capture can be identified in fish stomachs (Hyslop, 1980; Cortés, 1997). Moreover, some prey can be ingested without being assimilated by a consumer, resulting in biased estimations of prey contributions (Cortés, 1997). Prey with soft bodies is also likely to be more quickly digested than prey with hard structures, such as shelves or carapaces, resulting in over- or underestimation of prey importance in fish diet. Finally, diet quantification from stomach content analyses requires a large number of samples to be analyzed due to the high variability characterizing stomach fullness and content in most fish species (Cortés, 1997).

Stable isotopes have more recently emerged as a promising complementary methodology to address fish dietary ecology (e.g., Carassou et al., 2008; Gning et al., 2010; França et al., 2011; Davis et al., 2012; Carassou et al., 2016). Stable isotopes can be used as natural tracers of the sources of food assimilated by a consumer, relying on the principle that the isotopic composition of the food is reflected in the consumer tissues after some period of time ranging from weeks to months depending on species, environmental conditions and 
Author-produced version of the article published in Regional Studies in Marine Science, 2017, 16, 145-151 The original publication is available at http://www.sciencedirect.com/

doi : 10.1016/j.rsma.2017.08.008

consumer growth patterns (Bosley et al., 2002; Buchheister and Latour, 2010). In this context, stable isotopes of carbon $\left({ }^{13} \mathrm{C} /{ }^{12} \mathrm{C}\right.$, or $\left.\delta^{13} \mathrm{C}\right)$ and nitrogen $\left({ }^{15} \mathrm{~N} /{ }^{14} \mathrm{~N}\right.$, or $\left.\delta^{15} \mathrm{~N}\right)$ are the most often measured in food web studies (Hobson, 1999; Post, 2002). The combination of stomach content with $\delta^{13} \mathrm{C}$ and $\delta^{15} \mathrm{~N}$ analyses is now recognized as a pertinent methodology in order to quantify fish diet and address its spatial and temporal variability in a given ecosystem (Hamidan et al., 2016; Keller et al., 2016; Malek et al., 2016; Olson et al., 2016; Weidner et al., 2017). In addition to carbon and nitrogen isotopic ratios, sulfur isotopes are also useful to trace the origin of the prey consumed by consumers in aquatic ecosystems (Peterson, 1999; Post, 2002; Fry and Chumchal, 2011). The relative composition of ${ }^{34} \mathrm{~S} /{ }^{33} \mathrm{~S}\left(\delta^{34} \mathrm{~S}\right)$ in fish muscles, in particular, provides additional information to carbon and nitrogen isotopic ratios to unravel the identity and origin of basal resources used by mobile consumers, in particular prey origin, i.e., benthic or pelagic, as well as the diversity of potential resources constitutive of a consumer's diet (Peterson, 1999; Connolly et al., 2004; Jardine et al., 2012; Colborne et al., 2016; Morkūnè et al., 2016).

Only few published studies used stable isotopes to investigate wild fish diets in coastal waters of the Sultanate of Oman (Al-Reasi et al., 2007; Al-Habsi et al., 2008; Mill, 2007; Mill et al., 2007). For example, Al-Habsi et al. (2008) used carbon and nitrogen isotopic ratios to investigate a potential size-structuration of demersal food webs in the coastal area of the Arabian Sea (located on the south of the country). The same stable isotopes were used to analyze the trophodynamics of coral reef communities from the Arabian Sea and the Sea of Oman (located on the northwest of the country), the two sites being characterized by contrasted influences of regional upwelling (Mill, 2007). The later study (Mill, 2007) focused on fish species associated with reef habitats, using many $\delta^{13} \mathrm{C}$ and $\delta^{15} \mathrm{~N}$ observations and additional $\delta^{34} \mathrm{~S}$ on a restricted number of species, in an attempt to understand reef fishes' reliance on a variety of basal food resources on the reefs, and the influence of upwelling events on their trophic structure. The trophic structure of demersal fish communities in nonreef habitats from the Sea of Oman has never been studied using stable isotope analyses. In the present study, we therefore provide a preliminary analysis of stomach content, $\delta^{13} \mathrm{C}, \delta^{15} \mathrm{~N}$ and $\delta^{34} \mathrm{~S}$ data to investigate the trophic structure of demersal fish assemblages collected by trawling in soft-bottom Muscat coastal waters.

\section{Material and Methods}

2.1. $\quad$ Sampling site and methods 
Author-produced version of the article published in Regional Studies in Marine Science, 2017, 16, 145-151 The original publication is available at http://www.sciencedirect.com/

doi : 10.1016/j.rsma.2017.08.008

The Sea of Oman is located south of the Arabian Gulf, down the narrow Strait of Hormuz, and is open to the Arabian Sea to the south. It is relatively deep, with $3 / 4^{\text {th }}$ of its waters being more than 1,000 m depth (Rastgoo and Navarro, 2017). Oceanographic conditions characterizing the Sea of Oman are described in detail in Banse and Piontkovski (2006), Al-Hashmi et al. (2010), Piontkovski et al. (2011) and Piontkovski and Chiffings (2014). In short, Oman coastal waters are characterized by one of the most intensive coastal upwelling phenomena in the world (Reynolds, 1993; Al-Hashmi et al., 2010). A monsoonal regime drives a wind-driven circulation of the mixed layer, with recurrent formation of cyclonic and anti-cyclonic eddies affecting the vertical transport of nutrient rich and low oxygen sub-surface waters. In the Sea of Oman in particular, these vertical water movements generate a strong variability in water temperature, with stronger temperature variations observed between March and October, and relatively cooler and less variable temperature between November and February (Al-Hashmi et al., 2010). Water temperature at the subsurface $\left(8 \mathrm{~m}\right.$ depth) varies between $23^{\circ} \mathrm{C}$ in February and $33{ }^{\circ} \mathrm{C}$ in June on average (AlHashmi et al., 2010).

Fish samples were collected over the course of teaching field trips on board of the research vessel 'Al-Jamiah' during two periods: March and December 2014, and at a coastal location near the city of Muscat (fishing position starting $23^{\circ} 41^{\prime} 803 \mathrm{~N} 058^{\circ} 16^{\prime} 248 \mathrm{E}$, ending $23^{\circ} 40^{\prime} 949 \mathrm{~N} 058^{\circ} 19^{\prime} 126 \mathrm{E}$; Fig.1). As fish samples were collected opportunistically in an educational context, potential food resources consumed by fish could not be sampled. Our analysis was therefore restricted to a preliminary description of the overall trophic structure of fish consumers, with no analysis of their relationship with primary producers or any other group of fauna. Each trip consisted in one-day fishing event, with all trips undertaken at similar location. The fishing gear was a bottom trawl characterized by a $30 \mathrm{~m}^{2}$ opening, with a $12 \mathrm{~cm}$ mesh size in the wings and $6 \mathrm{~cm}$ mesh size in the bag. A total of 2 to 3 tows were performed at each sampling period. The trawl was towed at day-time during 30 minutes at a speed of about 2 knots. After each tow, fish species were sorted out on the boat and one to six specimens (depending on their availability) of different size for each species were placed on ice and immediately transported back to the laboratory.

\subsection{Laboratory work}

In the laboratory, all fish samples were measured as standard length $(\mathrm{cm})$, except for Aetomylaeus nichofii (banded eagle-ray) for which maximum wing width was measured. Stomachs of all fishes were removed and preserved in $5 \%$ formaldehyde (Sigma, USA) for 
Author-produced version of the article published in Regional Studies in Marine Science, 2017, 16, 145-151 The original publication is available at http://www.sciencedirect.com/

doi : 10.1016/j.rsma.2017.08.008

48 hours, before being transferred to $70 \%$ ethanol (Sigma, USA). Stomachs were later cut open and poured in a Petri dish (Bio-rad, USA). Fullness of stomachs were visually estimated (in \%) during dissection. Prey were identified to coarse taxonomic categories under a dissecting microscope. The relative abundance of prey categories was quantified by visually estimating the proportion (in \%) of different prey items relative to the total space occupied by the total stomach content in the Petri dish.

Samples for stable isotope analyses were prepared for one to three fish per species (replication depending on samples availability; Table 1). For each fish, one piece of dorsal muscle was dissected out, placed in an individual aluminum folder and frozen at $-80{ }^{\circ} \mathrm{C}$ for further storage. Then, fish muscle samples were defrosted and dried in an oven at $50{ }^{\circ} \mathrm{C}$ for 48 hours, before grinding with an ethanol-cleaned mortar and pestle. Samples of dried homogenized muscle powder were finally placed in tin capsules for stable isotope analysis performed at UC Davis Stable Isotope Facility laboratory (http://stableisotopefacility.ucdavis.edu/). One mg of the fish dry sample was used for $\delta^{13} \mathrm{C}$ and $\delta^{15} \mathrm{~N}$, while $3 \mathrm{mg}$ of the sample was used for $\delta^{34} \mathrm{~S}$ analyses. Lipids were not removed from our samples prior to analysis to avoid any protocol discrepancy among species and reduce $\delta^{13} \mathrm{C}, \delta^{15} \mathrm{C}$ and $\delta^{34} \mathrm{~S}$ dispersion (Post et al., 2007).

Measurement of dual ${ }^{13} \mathrm{C}:{ }^{12} \mathrm{C}$ and ${ }^{15} \mathrm{~N}:{ }^{14} \mathrm{~N}$ ratios in the samples was performed using a PDZ Europa ANCA-GSL elemental analyzer interfaced to a PDZ Europa 20-20 isotope ratio mass spectrometer ([IRMS] Sercon Ltd., Cheshire UK). Measurements of ${ }^{34} \mathrm{~S}:{ }^{33} \mathrm{~S}$ were performed using an Elementar vario ISOTOPE cube interfaced to a SerCon 20-22 IRMS (Sercon Ltd., Cheshire UK). $\delta^{13} \mathrm{C}, \delta^{15} \mathrm{~N}$ and $\delta^{34} \mathrm{~S}$ values were expressed relative to the international standards of Vienna PeeDee Belemnite, atmospheric $\mathrm{N}_{2}$ and Vienna-Canyon Diablo Troilite, respectively. Multipoint calibrations were done based on commercial standards IAEA-N1, N2 and N3 and USGS 40 and 41 for $\delta^{13} \mathrm{C}$ and $\delta^{15} \mathrm{~N}$, and IAEA-S1, S2 and $\mathrm{S} 3$ for $\delta^{34} \mathrm{~S}$. The experimental precision was calculated as the mean of standard deviations for within-run internal standards replicates for each analysis: \pm 0.09 for $\delta^{13} \mathrm{C}, \pm 0.08$ for $\delta^{15} \mathrm{~N}$ and \pm 0.22 for $\delta^{34} \mathrm{~S}$.

\subsection{Data analysis}

The occurrence (in \%) of different prey items into fishes' non-empty stomachs was averaged across sampling periods for each species, allowing to characterize their general feeding regime. Stable isotope data were plotted separately for each sampling season in two dimensional-spaces, i.e., $\delta^{13} \mathrm{C}$ vs. $\delta^{15} \mathrm{~N}$ and $\delta^{13} \mathrm{C}$ vs. $\delta^{34} \mathrm{~S}$. One-way analysis of variance 
Author-produced version of the article published in Regional Studies in Marine Science, 2017, 16, 145-151 The original publication is available at http://www.sciencedirect.com/

doi : 10.1016/j.rsma.2017.08.008

(ANOVA) was then used to test for significant differences $(P<0.05)$ between seasons in mean $\delta^{13} \mathrm{C}, \delta^{15} \mathrm{~N}$ and $\delta^{34} \mathrm{~S}$ (all species combined, d.f. $=1$ ). The overall $\delta^{13} \mathrm{C}$ and $\delta^{34} \mathrm{~S}$ variation range (i.e., maximum - minimum value) and variance characterizing fish communities at different periods were used to illustrate the global trophic niche utilized by the demersal fish community over time, i.e., the overall diversity of food resources used by fishes and their relative origins (benthic vs. pelagic, coastal vs. oceanic). The overall $\delta^{15} \mathrm{~N}$ range values and variance were also calculated to infer the diversity of trophic levels potentially represented in the demersal fish community at the two sampling periods, assuming that different positions in the food web would result in a difference of at least $3.4 \%$ between two trophic levels (Post, 2002; Post et al., 2007). Additionally, the relationship between community-level fish size (all species combined) and $\delta^{13} \mathrm{C}, \delta^{15} \mathrm{~N}$ and $\delta^{34} \mathrm{~S}$ were examined to test for a possible size structuration of trophic relationships within the demersal fish community, such as investigated in Al-Habsi et al. (2008). Those relationships were tested using linear regression models, and considered significant if $P<0.05$. The banded eagle ray Aetomylaeus nichofii was excluded from size vs. isotope ratios analyses as its size measurement method differed from other fish species.

\section{Results}

A total of 46 fish specimens representing 15 different species and 7 orders were collected over the two sampling periods (Table 1). This included 26 fish samples from 9 species in March 2014, 20 fish samples from 12 species in December 2014, and 6 species collected during both periods. Overall size range of the fish community was 7.5 to $55.0 \mathrm{~cm}$ SL (excluding the banded eagle ray Aetomylaeus nichofii) (Table 1). Among the 46 fish dissected for stomach content analyses, 12 (26\%) had empty stomachs, including two species for which only one specimen was collected, resulting in no available data for diet analysis. A total of 29 individual fish could be analyzed for dual carbon and nitrogen isotopes, and 27 for sulfur isotopes (Table 1).

All 13 species for which prey could be observed in the stomachs were characterized by a clear carnivorous diet, with variable contributions of fish and invertebrate prey (Table 2). Only Fistularia petimba (species 15) had consumed exclusively fish prey, but fish prey were also observed in all stomachs of Saurida tumbil (species 1) and Ulua mentalis (species 4), and in one third (33\%) of the stomachs of Nemipterus bipunctatus (species 8 ) and Pelates quadrilineatus (species 11) (Table 2). Crabs (Brachyura, Crustacea) occurred in all stomachs of Plectorhynchus pictus (species 6), Argyrops spinifer (species 10) and Arius thalassinus 
Author-produced version of the article published in Regional Studies in Marine Science, 2017, 16, 145-151 The original publication is available at http://www.sciencedirect.com/

doi : 10.1016/j.rsma.2017.08.008

(species 14). At least half of analyzed stomachs of N. bipunctatus, Nemipterus japonicus (species 9), and Pseudorhombus arsius (species 12) contained crabs as well (Table 2). Shrimps (Dendrobranchiata, Crustacea) were found in all stomachs of U. mentalis, P. pictus and $N$. japonicus and in at least half of the stomachs analyzed for Aetomylaeus nichofii (species 2), Taeniamia fucata (species 3), N. bipunctatus, A. spinifer, and P. quadrilineatus. At least a quarter of analyzed stomachs for $S$. tumbil and $P$. arsius were also filled with shrimps. Manta shrimps (Stomatopoda, Crustacea) were observed in the stomach of one individual N. bipunctatus. Mollusks (Gastropoda) were also abundant prey items (Table 2). Gastropods occurred in P. pictus stomachs, and in one third of N. japonicus and A. spinifer stomachs. Annelida (Polychaetes) were only observed in stomachs of N. bipunctatus. Other prey items recorded included unidentified crustaceans and particulate organic matter (detritus) (Table 2).

Seasonal variations in mean $\delta^{15} \mathrm{~N}$ were not significant (Table 3). However, $\delta^{15} \mathrm{~N}$ levels characterizing the demersal fish community varied from 14.19 to $16.89 \%$ in March and from 14.85 to $16.88 \%$ in December, resulting in an overall $\delta^{15} \mathrm{~N}$ variation range lower in December than in March (2.03 and $2.7 \%$, respectively), consistently with a lower variance in December (Table 3). A more contracted trophic structure with lower variations in trophic positions among species was therefore observed in December compared to March (Fig. 2). Observed $\delta^{15} \mathrm{~N}$ variation ranges were also largely inferior to the threshold level of $3.4 \%$ characterizing a change in trophic position.

Seasonal variations in mean $\delta^{13} \mathrm{C}$ were not significant either (Table 3). However, $\delta^{13} \mathrm{C}$ varied from -17.24 to $-15.11 \%$ in March and from -17.48 to -13.58 in December, corresponding to an overall $\delta^{13} \mathrm{C}$ variation range of 2.13 and $3.9 \%$, respectively. Similarly, $\delta^{13} \mathrm{C}$ variance was lower in March than in December (Table 3) Accordingly, the fish community trophic structure appeared more widely distributed along the $\delta^{13} \mathrm{C}$ axis in December (Figs. 2 and 3), implying a larger variability in the nature and origin of food resources consumed by fishes during that month. This pattern was confirmed by observed variability in $\delta^{34} \mathrm{~S}$ values, which varied from $13.56 \%$ to $10.23 \%$ in March and from $13.03 \%$ to $19.09 \%$ in December. The overall $\delta^{34} \mathrm{~S}$ variation range was therefore slightly larger in December (6.06 \%) than in March (5.67\%), consistently with variance values (Table 3), although difference between months in mean $\delta^{34} \mathrm{~S}$ was not significant (Table 3). The fish community trophic structure therefore appeared slightly more widely distributed along both the $\delta^{13} \mathrm{C}$ and $\delta^{34} \mathrm{~S}$ axes in December compared to in March (Fig. 3), confirming the consumption by fishes of food resources from more diverse mixture and origin in December. 
Author-produced version of the article published in Regional Studies in Marine Science, 2017, 16, 145-151 The original publication is available at http://www.sciencedirect.com/

doi : 10.1016/j.rsma.2017.08.008

Species-specific $\delta^{13} \mathrm{C}, \delta^{15} \mathrm{~N}$ and $\delta^{34} \mathrm{~S}$ values differed little between the two periods (Figs. 2 and 3). Regarding fish size, only $\delta^{15} \mathrm{~N}$ values appeared to significantly $(P<0.05)$ vary according to the size structure of the fish community, with larger species having higher nitrogen isotope ratios (Fig. 4). However, this relationship was weak $\left(r^{2}=0.36\right)$.

\section{Discussion}

Our study highlighted a clear carnivorous diet, with a heavy reliance on invertebrate and fish prey, for all fish species examined in Muscat coastal waters. Fish prey was found in relatively large proportions in stomachs of some species, such as redcornet fish (Fistularia petimba), greater lizardfish (Saurida tumbil), long raker trevally (Ulua mentalis), Delagoa threadfin bream (Nemipterus bipunctatus) and four lined terapon (Pelates quadrilineatus). However, the $\delta^{15} \mathrm{~N}$ values of these species largely overlapped with those ones in stomachs of which mostly invertebrate prey was found. Furthermore, the overall $\delta^{15} \mathrm{~N}$ values obtained at the community level had relatively narrow range, lower than the $3.4 \%$ threshold value usually characterizing the difference in nitrogen isotope composition between two consecutive trophic levels (Post, 2002; Post et al., 2007). This suggests that all species analyzed in our study had a similar trophic position in the food web. Therefore, our results indicate a largely mixed fish-invertebrate diet for most of demersal fish species in the Sea of Oman. Our results therefore highlight how essential insights from stable isotope analysis had proven to complement stomach content data, in order to fully apprehend the variability in feeding habits of consumers. Similar conclusions have been presented by recent studies (Carassou et al., 2016 and 2017; Keller et al., 2016; Olson et al., 2016). Stomach contents indeed only provide very short-term information on consumer's diet, while isotopic ratios in the tissues reflect dietary habits over longer time scales (Cortés, 1997; Hobson, 1999; Post, 2002; Olson et al., 2016). In our study in particular, the low number of specimens collected for each species, together with the occurrence of fish with empty stomachs, further limited the efficiency of stomach content analysis for capturing the full range and variability in prey diversity characterizing demersal fish feeding regimen.

As our study is the first one to address diet of demersal fish from soft-bottom habitats with stable isotopes in the Sea of Oman, comparisons with similar studies in the region is difficult. The study of Mill (2007) was focused on coral-reef associated fish species and it did not include any species common with our study. Only one fish species, Argyrops spinifer, which was collected in our study, was also analyzed by Al-Habsi et al. (2008) in the Arabian Sea. Comparison of the data suggested that A. spinifer from the Arabian Sea and the Sea of 
Author-produced version of the article published in Regional Studies in Marine Science, 2017, 16, 145-151 The original publication is available at http://www.sciencedirect.com/

doi : 10.1016/j.rsma.2017.08.008

Oman has very close values of $\delta^{13} \mathrm{C}$ (mean \pm standard deviation of $-15.91 \pm 0.10$ and -15.99 \pm 0.04 , respectively) and $\delta^{15} \mathrm{~N}(17.10 \pm 032$ and $15.18 \pm 0.82$, respectively). This suggests little variation in A. spinifer diet across different coastal regions in Oman waters, although no stomach content records or isotope data on the fish potential food resources were available for comparison in Al-Habsi et al. (2008). In a recent study, Rastgoo and Navarro (2017) reviewed stomach content data available from 21 finfish species of the Sea of Oman to infer their respective trophic levels. Only two species were common to our study: Nemipterus japonicus and Saurida tumbil, with both being characterized by a trophic level $\geq$ to 4 , indicating a carnivorous diet dominated by the consumption of fish prey or high-order invertebrate consumers. Our study highlighted a similar result, although stable isotope data highlighted a probable mixture of fish and invertebrate prey for both species.

Al-Habsi et al. (2008) found an apparent size-related structuration in $\delta^{15} \mathrm{~N}$ and $\delta^{13} \mathrm{C}$ values at the demersal fish community level in the Arabian Sea, although such size structure was not apparent at the level of species. In our study in the Sea of Oman, no significant relationship between fish size and isotope ratios were evident at the demersal fish community level, except for $\delta^{15} \mathrm{~N}$ which increased with fish size but with a low regression coefficient $\left(\mathrm{r}^{2}<\right.$ 0.4). Rastgoo and Navarro (2017) also reported a positive correlation between trophic levels estimated from stomach content data in the literature, and fish size in the Sea of Oman. Based on a restricted number of samples, those relationships could however not be tested at the species level in our study. This aspect should therefore be the focus of more future studies in the Sea of Oman, in order to explicit the size-related variability in demersal fish diet in this particular region. Issues of size-related structuration in ecological traits characterizing fish communities indeed have crucial implications in terms of fisheries management locally, since, as emphasized in Al-Habsi et al. (2008), size-based metrics are increasingly promoted to assess fishing impacts on natural communities at an ecosystem scale.

Analysis of stable isotope data conducted herein also suggest a possible seasonal change in the range of diversity and origin of prey consumed by demersal fish in the studied area, reflected by a larger range and variance of $\delta^{13} \mathrm{C}$ (and $\delta^{34} \mathrm{~S}$ to a lesser degree) values in December compared to March. Indeed, carbon and sulfur isotopic ratios depends not only on the nature of prey contributing to consumers' diet, but also on their origin such as benthic vs. pelagic or coastal vs. marine (Hobson, 1999; Layman et al., 2012). Accordingly, along the $\delta^{13} \mathrm{C}$ and $\delta^{34} \mathrm{~S}$ gradients, the trophic structure of demersal fish community appeared relatively 'relaxed' in December, and more 'contracted' in March (although variations in mean values between seasons were not significant for any isotope). . This apparent change in the trophic 
Author-produced version of the article published in Regional Studies in Marine Science, 2017, 16, 145-151 The original publication is available at http://www.sciencedirect.com/

doi : 10.1016/j.rsma.2017.08.008

structure may logically reflect seasonal changes in oceanographic conditions in our study area, in particular variations in water temperature, water column mixing and primary productivity related to the seasonal monsoon (Piontkovski et al., 2011). Stronger winds occurring during the monsoon season, extending from March/April to September/October, result in a stronger mixing of the water column, as highlighted by highly variable patterns of water temperature during this period (Al-Hashmi et al., 2010). Stable isotope composition in fish muscles reflects food assimilation along periods ranging from weeks to months, depending on species and life stages (Buchheister and Latour, 2010). Therefore, it is likely that fish collected at the end of the monsoon period, i.e., in December, have been feeding in a marine environment with increased re-suspension of material from the bottom (e.g., sediments) to the middle and surface layers of the water column, and enhanced exchanges between coastal and offshore water masses. Such resuspension and mixing processes potentially resulted into a larger set of prey origin available for fish in December (mixture of surface, bottom and/or coastal, marine fueled prey), as compared to fish collected at the beginning of the monsoon, i.e., in March, which have likely been feeding upon prey relying on basal resources from a more restricted range of environmental conditions. This hypothesis should be tested in future studies, as the low number of analyzed samples in our study precludes any clear conclusion to be drawn in this regards.

Although limited in sampling effort and lack of spatial replication, this study highlights the utility of detailed dietary studies to improve our understanding on demersal fish community structure in a data poor region. Even based on a small data set, this study emphasized some clear and interesting features characterizing the trophic structure of demersal fish communities, demonstrating the utility of the approach to inform fishery management in the Sea of Oman. The use of stable isotopes to address fish dietary requirements and relationships also remains novel for the entire country, as highlighted by the scarcity of studies addressing this issue in our region. We therefore strongly advocate for complementary investigations to be implemented based on this methodology, in order to not only improve knowledge on the trophic ecology of the highly diverse fish assemblages characterizing the coastal environment of Oman (Al-Jufaily et al., 2010), but also to contribute to the development of ecosystem-based approaches to the management of local fisheries, which have a crucial economic and cultural importance in the region (Sideek et al., 1999; Valinassab et al., 2006). Such future studies should rely on an appropriately designed and intensive sampling of both fish and their potential prey at contrasted seasons and locations, so as to: 1) provide necessary data for the calculation of consumer trophic positions 
Author-produced version of the article published in Regional Studies in Marine Science, 2017, 16, 145-151 The original publication is available at http://www.sciencedirect.com/

doi : 10.1016/j.rsma.2017.08.008

based on precise stable isotope data, as mean trophic level of commercial species are an important parameter from a fisheries management perspective (see for example Abd ElRahman, 2014 for a case study in Oman), and 2) incorporation of stable isotope data into mixing models for estimating food resource contribution in supporting demersal fish community diet across time and space.

\section{Acknowledgements}

This study was supported by the funds from College of Agricultural and Marine Sciences, Sultan Qaboos University - Dean's discretionary funds (IG/AGR/Dean/14/01). We thank all students from cohorts Fall 2014, Spring 2015 and Fall 2015 of the Introduction to Marine Science and Fisheries course (MASF2003) for participation in field sampling. We are also grateful to Mr. Khamis Al-Riyami, Mr. Farid Al-Abdali, captain Mr. Saleh Al-Maashari, and boat engineer Mr. Manolito Barate. From the UC Davis Stable Isotope facility, we thank Dr Joy Matthews and Dr Chris Yarnes for carbon/nitrogen and sulfur analyses, respectively, and Ms. Emily Schick for administrative and accounting support. 
Author-produced version of the article published in Regional Studies in Marine Science, 2017, 16, 145-151 The original publication is available at http://www.sciencedirect.com/

doi : 10.1016/j.rsma.2017.08.008

\section{References}

Abd El-Rahman, M.A.E.B., 2014. A bio-economic study of the trophic structure of the omani fish catch. Trop. Life Sci. Res. 25, 29-40.

Al-Habsi, S.H., Sweeting, C.J., Polunin, N.V.C., Graham, N.A.J., 2008. $\delta^{13} \mathrm{C}$ and $\delta^{15} \mathrm{~N}$ elucidation of size-structured food webs in a Western Arabian Sea demersal trawl assemblage. Mar. Ecol. Prog. Ser. 353, 55-63.

Al-Hashmi, K.A., Claereboudt, M.R, Al-Azri, A.R., Piontkovski, S.A., 2010. Seasonal changes of Chlorophyll $a$ and environmental characteristics in the Sea of Oman. The Open Oceanogr. J. 4, 107-114.

Al-Jufaily, S.M., Hermosa, G., Al-Shuaily, S.S., Mujaini, A.A., 2010. Oman fish biodiversity. Journal of King Abdulaziz University. Mar. Sci. 21, 3-51.

Al-Reasi, H.A., Ababneh, F.A., Lean, D.R., 2007. Evaluating mercury biomagnification in fish from a tropical marine environment using stable isotopes $\left(\delta^{13} \mathrm{C}\right.$ and $\left.\delta^{15} \mathrm{~N}\right)$, Environ. Toxicol. Chem. 26, 1572-1581.

Banse, K., Piontkovski, S.A. (eds.), 2006. The mesoscale structure of the epipelagic ecosystem of the open Northern Arabian Sea. Universities Press, Hyderabad, India.

Bosley, K.L., Witting, D.A., Chambers, C.R., Wainright, S.C., 2002. Estimating turnover rates of carbon and nitrogen in recently metamorphosed winter flounder Pseudopleuronectes americanus with stable isotopes. Mar. Ecol. Prog. Ser. 236, 233240.

Buchheister, A., Latour, R.J., 2010. Turnover and fractionation of carbon and nitrogen stable isotopes in tissues of a migratory coastal predator, summer flounder (Paralichthys dentatus). Can. J. Fish. Aquat. Sci. 67, 445-461.

Carassou, L., Kulbicki, M., Nicola, T.J.R., Polunin, N.V.C., 2008. Assessment of fish trophic status and relationships by stable isotope data in the coral reef lagoon of New Caledonia, southwest Pacific. Aquat. Liv. Res. 21, 1-12.

Carassou, L., Whitfield, A.K., Bergamino, L., Moyo, S., Richoux, N.B., 2016. Trophic dynamics of the Cape stumpnose (Rhabdosargus holubi, Sparidae) across three adjacent aquatic habitats. Estuar. Coasts 39, 1221-1233.

Carassou, L., Whitfield, A.K., Moyo, S., Richoux, N.B., 2017. Dietary tracers and stomach contents reveal pronounced alimentary flexibility in the freshwater mullet (Myxus capensis, Mugilidae) concomitant with ontogenetic shifts in habitat use and seasonal food availability. Hydrobiologia 799, 327-348. 
Author-produced version of the article published in Regional Studies in Marine Science, 2017, 16, 145-151 The original publication is available at http://www.sciencedirect.com/

doi : 10.1016/j.rsma.2017.08.008

Colborne, S.F., Rush, S.A., Paterson, G., Johnson, T.B., Lantry, B.F., Fisk, A.T., 2016. Estimates of lake trout (Salvelinus namaycush) diet in Lake Ontario using two and three isotope mixing models. J. Great Lakes Res. 42, 695-702.

Connolly, R.M., Guest, M.A., Melville, A.J., Oakes, J.M., 2004. Sulfur stable isotopes separate producers in marine food-web analysis. Oecologia 138, 161-167.

Cortés, E., 1997. A critical review of methods of studying fish feeding based on analysis of stomach contents: application to elasmobranch fished. Can. J. Fish. Aquat. Sci. 54, 726738.

Davis, A.M., Blanchette, M.L., Pusey, B.J., Jardine, T.D., Pearson, R.G., 2012. Gut content and stable isotope analyses provide complementary understanding of ontogenetic dietary shifts and trophic relationships among fished in a tropical river. Freshw. Biol. 50, 2156-2172.

Fogarty, M.J., 2013. The art of ecosystem-based fishery management. Can. J. Fish. Aquat. Sci. 71, 479-490.

França, S., Vasconcelos, R.P., Tanner, S., Máguas, C., Costa, M.J., Cabral, H.N., 2011. Assessing food web dynamics and relative importance of organic matter sources for fish species in two Portuguese estuaries: a stable isotope approach. Mar. Environ. Res. 72, 204-215.

Froese, R., Pauly, D. (eds.), 2017. Fishbase. World Wide Web electronic publication. www.fishbase.org. Version 1/2017.

Fry, B., Chumchal, M.M., 2011. Sulfur stable isotopes indicators of residency in estuarine fish. Limn. Oceanogr. 56, 1563-1576.

Gning, N., Le Loc'h, F., Thiaw, O.T., Aliaume, C., Vidy, G., 2010. Estuarine resources use by juvenile Flagfin mojarra (Eucinostomus melanopterus) in an inverse tropical estuary. Estuar. Coast. Mar. Sci. 86, 683-691.

Gorospe, K.D., Michael, W., Pomeroy, R., Elvidge, C., Lynch, P., Wongbusarakum, S., Brainard, R.E., 2016. The mobilization of science and technology fisheries innovations towards an ecosystem approach to fisheries management in the Coral Triangle and Southeast Asia. Mar. Policy 74, 143-152.

Hamidan, N., Jackson, M.C., Britton, J.R., 2016. Diet and trophic niche of the endangered fish Garra ghorensis in three Jordanian populations. Ecol. Freshw. Fish 25, 455-464.

Hobson, K.A., 1999. Tracing origins and migration of wildlife using stable isotopes: a review. Oecologia 120, 314-326. 
Author-produced version of the article published in Regional Studies in Marine Science, 2017, 16, 145-151 The original publication is available at http://www.sciencedirect.com/

doi : 10.1016/j.rsma.2017.08.008

Hyslop, E.J., 1980. Stomach contents analysis - a review of methods and their application. J. Fish Biol. 17, 411-429.

Jardine, T., Pusey, B., Hamilton, S., Pettit, N., Davies, P., Douglas, M., Sinnamon, V., Halliday, I., Bunn, S., 2012. Fish mediate high food web connectivity in the lower reaches of a tropical floodplain river. Oecologia 168, 829-838.

Keller, H.R., Hirons, A.C., Kerstetter, D.W., 2016. Combined stomach content and $\delta^{13} \mathrm{C} / \delta^{15} \mathrm{~N}$ analyses of oilfish, escolar, snake mackerel and lancetfish in the western North Atlantic. Mar. Ecol. 37, 727-736.

Layman, C.A., Araujo, M.S., Boucek, R., Hammerschlag-Peyer, C.M., Harrison, E., Jud, Z.R., Matich, P., Rosenblatt, A.E., Vaudo, J.J., Yeager, L.A., Post, D.M., Bearshop, S., 2012. Applying stable isotopes to examine food-web structure: an overview of analytical tools. Biol. Rev. 87, 545-562.

Malek, A.J., Collie, J.S., Taylor, D.L., 2016. Trophic structure of a coastal fish community determined with diet and stable isotope analyses. J. Fish Biol. 89, 1513-1536.

Mill, A., 2007. Stable isotope data as reef food-web descriptors in a dynamic tropical environment. $\mathrm{PhD}$ thesis, University of Newcastle, Newcastle.

Mill, A.C., Pinnegar, J. K., Polunin, N.V.C., 2007. Explaining isotope trophic-step fractionation: why herbivorous fish are different. Funct. Ecol. 21, 1137-1145.

Morkūnè, R., Lesutienè, J., Barisevičiūtè, R., Morkūnas, J., Gasiūnaitė, Z.R., 2016. Food sources of wintering piscivorous waterbirds in coastal waters: a triple stable isotope approach for the southeastern Baltic Sea. Estuar. Coast. Shelf Sci. 171, 41-50.

Olson, K.W., Jensen, O.P., Hrabik, T.R., 2016. Feeding ecology and prey resource partitioning of lenok (Brachymystax lenok) and Baikal grayling (Thymallus arcticus baicalensis) in the Eg and Uur rivers, Mongolia. Ecol. Freshwa. Fish 25, 565-576.

Pauly, D., Christensen, V., Guénette, S., Pitcher, T.J., Sumaila, U.R., Walters, C.J., Watson, R., Zeller, D., 2002. Towards sustainability in world fisheries. Nature 418, 689-695.

Peterson, B.J., 1999. Stable isotopes as tracers of organic matter input and transfer in benthic food webs: a review. Acta Oecolog. 20, 479-487.

Piontkovski, S.A., Chiffings, T., 2014. Long-term changes of temperature in the Sea of oman and the Western Arabian Sea. Internat. J. Oceans Oceanogr. 8, 53-72.

Piontkovski, S., Al-Azri, A., Al-Hashmi, K., 2011. Seasonal and interannual variability of chlorophyll $a$ in the Gulf of Oman compared to the open Arabian Sea regions. Internat. J. Remote Sens. 32, 7703-7715. 
Author-produced version of the article published in Regional Studies in Marine Science, 2017, 16, 145-151 The original publication is available at http://www.sciencedirect.com/

doi : 10.1016/j.rsma.2017.08.008

Post, D.M., 2002. Using stable isotopes to estimate trophic position: models, methods, and assumptions. Ecology 83, 703-718.

Post, D.M., Layman, C.A., Arrington, D.A., Takimoto, G., Quattrochi, J., Montaña, C.G., 2007. Getting to the fat of the matter: models, methods and assumptions for dealing with lipids in stable isotope analysis. Oecologia 152, 179-189.

Rastgoo, A.R., Navarro, J., 2017. Trophic levels of teleost and elasmobranch species in the Persian Gulf and Oman Sea. J. Appl. Ichthyol. 33, 403-408.

Reynolds, R.M., 1993. Physical oceanography of the Gulf, Strait of Hormuz, and the Gulf of Oman: results from the Mitchell Expedition. Mar. Poll. Bull. 27, 35-60.

Sideek, M.S.M., Fouda, M.M., Hermosa, G.V.Jr., 1999. Demersal fisheries of the Arabian Sea, the Gulf of Oman and the Arabian Gulf. Estuar. Coast. Shelf Sci. 49 suppl. A, 8797.

Starr, R.M., Carr, M., Malone, D., Greenley, A., McMillan, S., 2010. Complementary sampling methods to inform ecosystem-based management of nearshore fisheries. Mar. Coast. Fish. 2, 159-179.

Valinassab, T., Daryanabard, R., Dehghani, R., Pierce, G.J., 2006. Abundance of demersal fish resources in the Persian Gulf and Oman Sea. J. Mar. Biol. Assoc. U.K. 86, 14551462.

Weidner, T.A., Hirons, A.C., Leavitt, A., Kerstetter, D.W., 2017. Combined gut-content and stable isotope trophic analysis of the pelagic stingray Ptereplaytrygon violacea (Bonaparte, 1832) diet from the western North Atlantic Ocean. J. Appl. Ichthyol., in press. 
Author-produced version of the article published in Regional Studies in Marine Science, 2017, 16, 145-151 The original publication is available at http://www.sciencedirect.com/

doi : 10.1016/j.rsma.2017.08.008

\section{Figure captions}

Fig.1: Location of the sampling site (red star) in the coastal area of Muscat, Sea of Oman.

Fig.2: Mean (circles) and standard deviation (error bars) of $\delta^{13} \mathrm{C}$ (x-axis) and $\delta^{15} \mathrm{~N}$ (y-axis) values measured in dorsal muscle of demersal fishes collected by trawling in Muscat coastal area. Numbers within circles indicate species codes, which are depicted in Table 1.

Fig. 3: Mean (circles) and standard deviation (error bars) of $\delta^{13} \mathrm{C}$ (x-axis) and $\delta^{34} \mathrm{~S}$ (y-axis) values measured in dorsal muscle of demersal fishes collected by trawling in Muscat coastal area. Numbers within circles indicate species codes, which are depicted in Table 1.

Fig. 4: Relationships between fish size (x-axis) and a) $\delta^{13} \mathrm{C}$, b) $\delta^{15} \mathrm{~N}$ and c) $\delta^{34} \mathrm{~S}$ values characterizing demersal fish community sampled in Muscat coastal area. Regression line and coefficient are only shown if the tested relationship is significant $(P<0.05)$. 


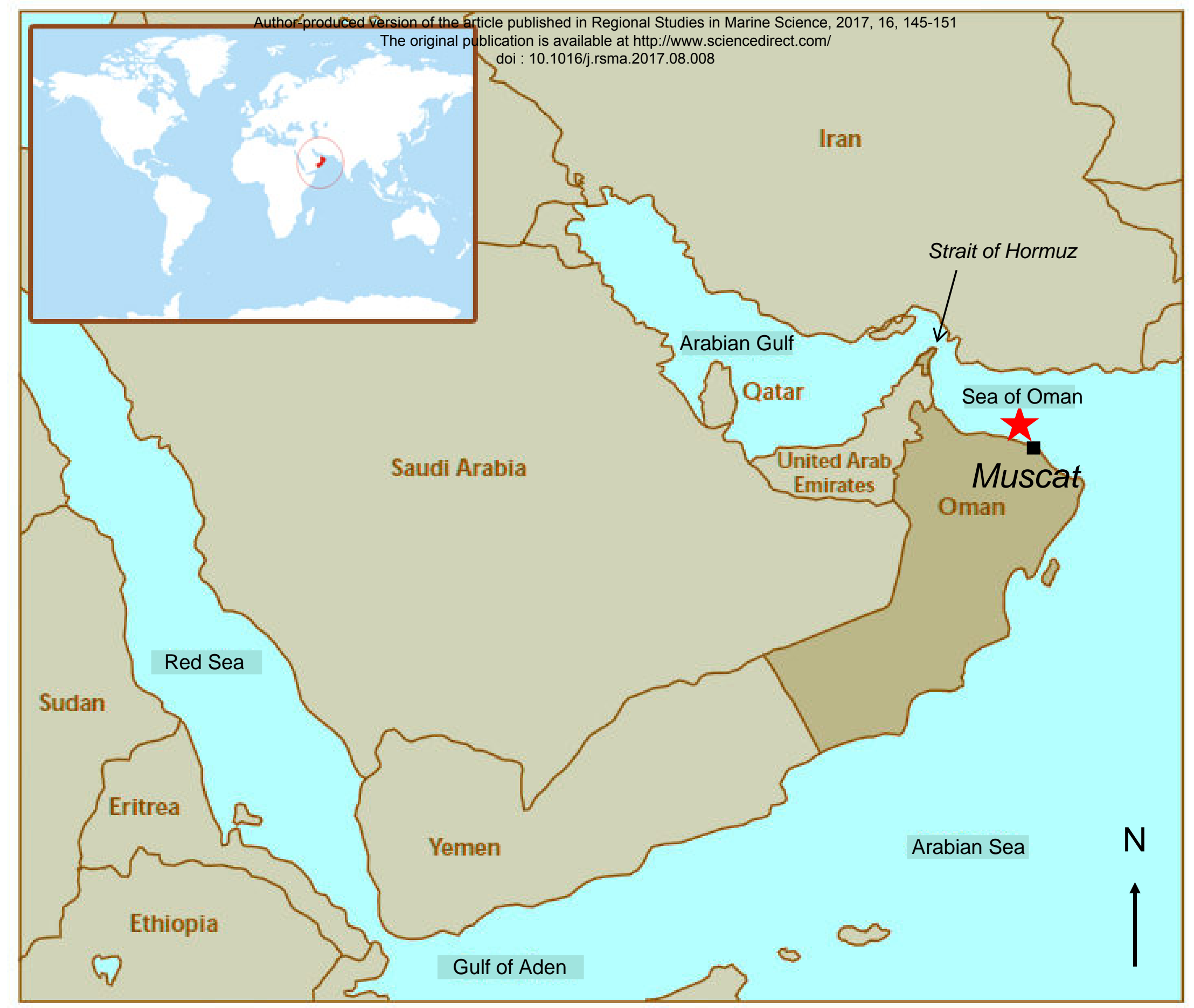


Author-produced version of the article published in Regional Studies in Marine Science, 2017, 16, 145-151 The original publication is available at http://www.sciencedirect.com/

doi : 10.1016/j.rsma.2017.08.008
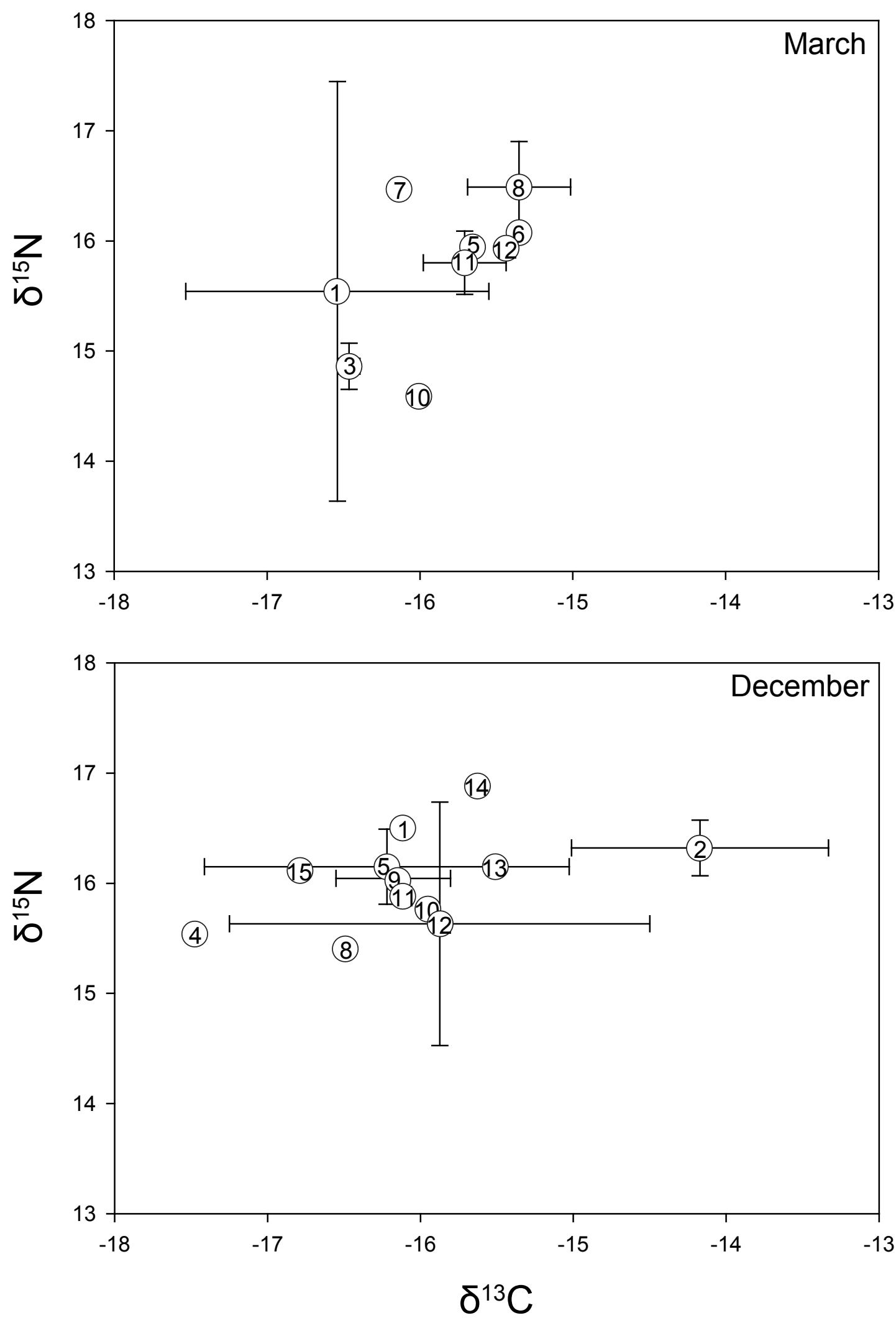
Author-produced version of the article published in Regional Studies in Marine Science, 2017, 16, 145-151 The original publication is available at http://www.sciencedirect.com/

doi : 10.1016/j.rsma.2017.08.008
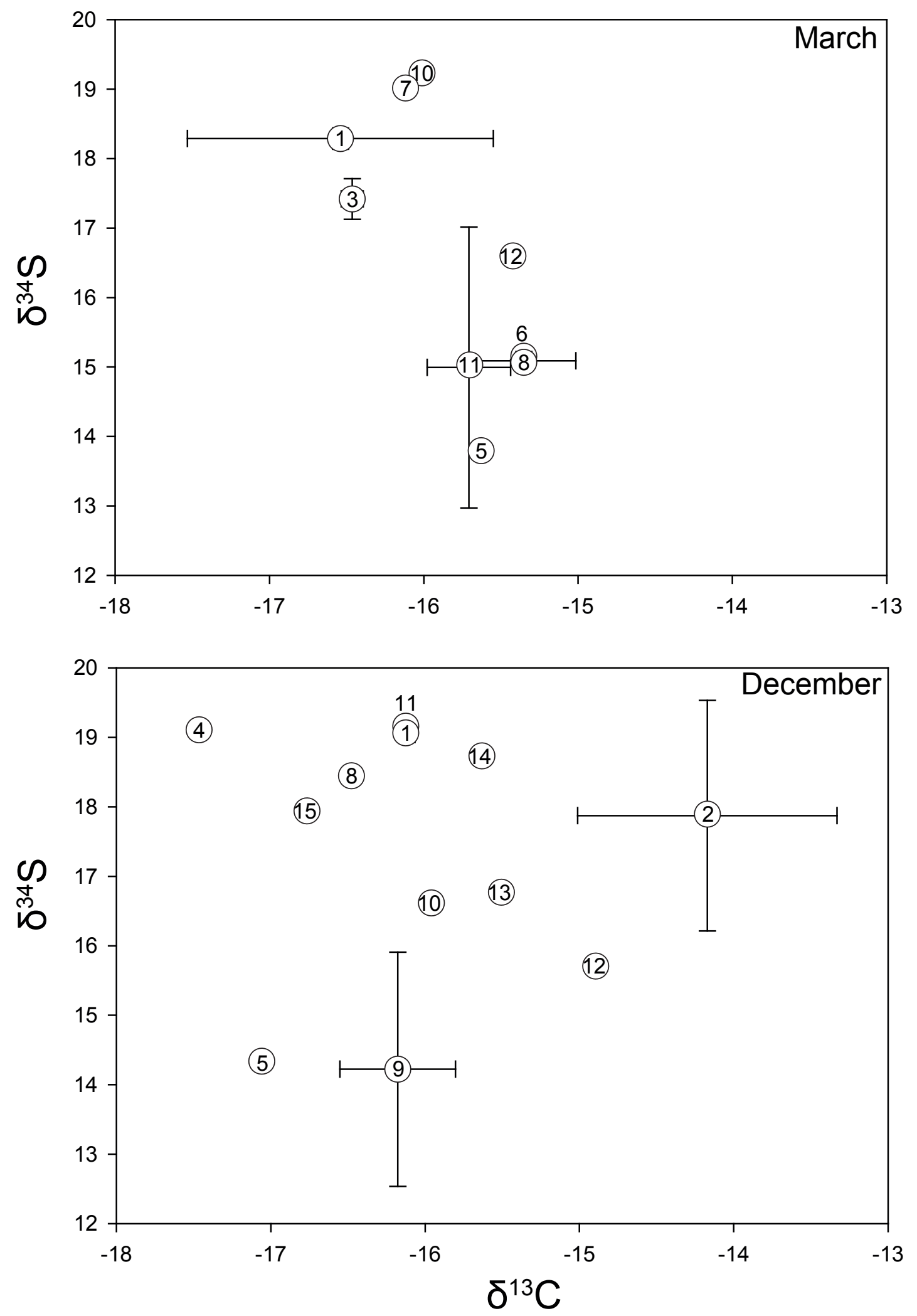

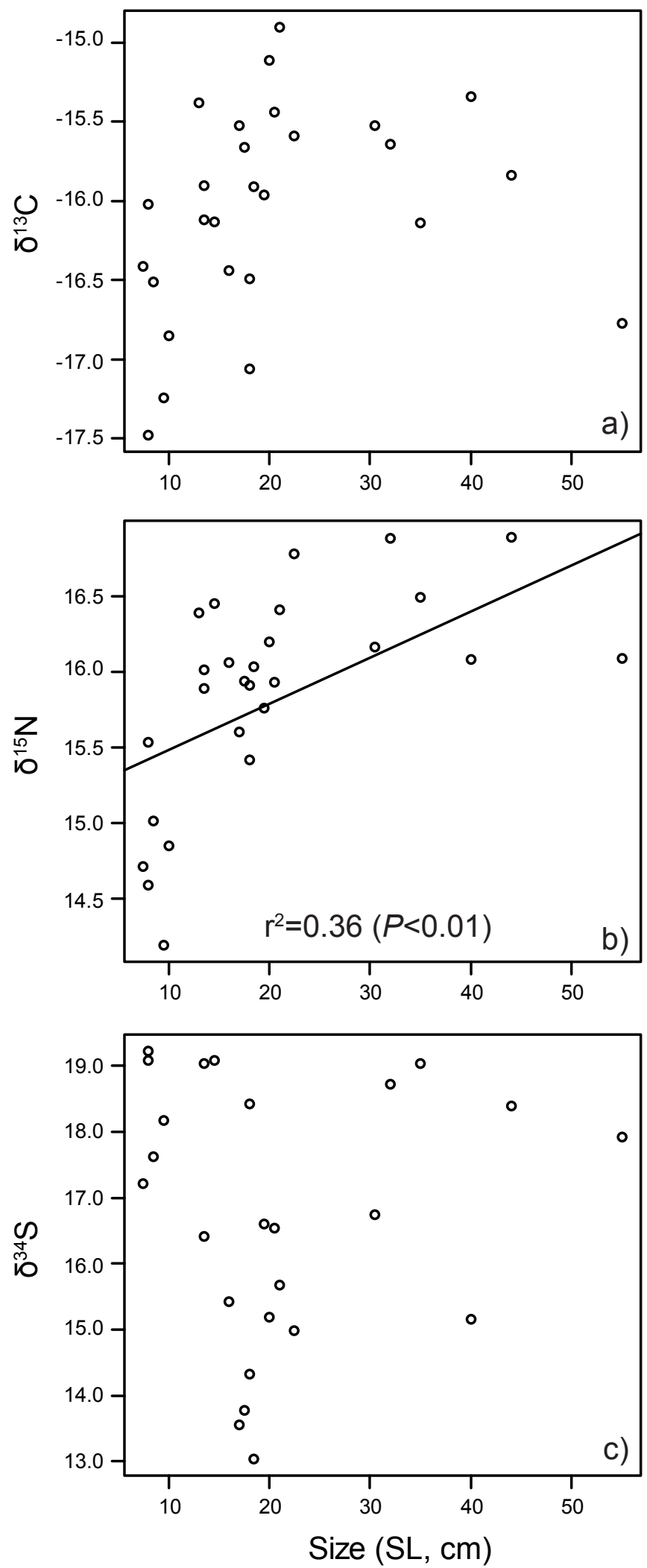
Table 1: Number and size range (min-max as SL in cm, except for banded eagle ray Aetomylaeus nichoffi for which size is given as maximum wing width in $\mathrm{cm}$ ) of fishes collected off Muscat coastal area in March (Mar) and December (Dec) 2014 for diet studies, with corresponding species codes and number of replicates analyzed for stomach content and stable isotope $\left(\delta^{13} \mathrm{C}, \delta^{15} \mathrm{~N}, \delta^{34} \mathrm{~S}\right)$ analyses. Numbers in brackets in the stomach contents' column indicate the number of fish for which stomachs were empty and therefore data not used for prey occurrence calculation.

\begin{tabular}{|c|c|c|c|c|c|c|c|c|c|c|c|c|c|}
\hline \multirow{3}{*}{ Order } & \multirow{3}{*}{ Family } & \multirow{3}{*}{ Genus } & \multirow{3}{*}{ Species } & \multirow{3}{*}{ Common name } & \multirow{3}{*}{ Code } & \multirow{2}{*}{\multicolumn{3}{|c|}{$\begin{array}{l}\text { Number of individuals } \\
\text { collected }\end{array}$}} & \multirow{3}{*}{ Size range } & \multicolumn{4}{|c|}{ Number of replicates analyzed } \\
\hline & & & & & & & & & & \multirow{2}{*}{$\begin{array}{l}\text { Stomach } \\
\text { contents }\end{array}$} & \multirow{2}{*}{$\delta^{13} \mathrm{C}$} & \multirow{2}{*}{$\delta^{15} \mathrm{~N}$} & \multirow{2}{*}{$\delta^{34} S$} \\
\hline & & & & & & Mar & Dec & Total & & & & & \\
\hline Aulopiformes & Synodontidae & Saurida & tumbil & Greater lizardfish & 1 & 6 & 1 & 7 & $9,5-44,0$ & $7(3)$ & 3 & 3 & 3 \\
\hline Myliobatiformes & Myliobatidae & Aetomylaeus & nichofii & Banded eagle ray & 2 & 0 & 2 & 2 & $28,0-50,0$ & $2(0)$ & 2 & 2 & 2 \\
\hline Perciformes & Apogonidae & Taeniamia & fucata & Orangelined cardinalfish & 3 & 4 & 0 & 4 & $7,5-8,5$ & $4(2)$ & 2 & 2 & 2 \\
\hline Perciformes & Carangidae & Ulua & mentalis & Longrackered trevally & 4 & 0 & 1 & 1 & 8,0 & $1(0)$ & 1 & 1 & 1 \\
\hline Perciformes & Gerreidae & Gerres & filamentosus & Whipfin silver-biddy & 5 & 1 & 3 & 4 & $13,0-18,0$ & $4(1)$ & 3 & 3 & 2 \\
\hline Perciformes & Haemulidae & Plectorhynchus & pictus & Trout sweetlips & 6 & 1 & 0 & 1 & 40,0 & $1(0)$ & 1 & 1 & 1 \\
\hline Perciformes & Lutjanidae & Lutjanus & lutjanus & Bigeye snapper & 7 & 1 & 0 & 1 & 14,5 & $1(1)$ & 1 & 1 & 1 \\
\hline Perciformes & Nemipteridae & Nemipterus & bipunctatus & Delagoa threadfin bream & 8 & 5 & 1 & 6 & $18,0-22,5$ & $6(0)$ & 3 & 3 & 3 \\
\hline Perciformes & Nemipteridae & Nemipterus & japonicus & Japanese threadfin bream & 9 & 0 & 3 & 3 & $16,0-18,5$ & $3(0)$ & 2 & 2 & 2 \\
\hline Perciformes & Sparidae & Argyrops & spinifer & King solder bream & 10 & 1 & 2 & 3 & $8,0-19,5$ & $3(0)$ & 2 & 2 & 2 \\
\hline Perciformes & Terapontidae & Pelates & quadrilineatus & Fourlined terapon & 11 & 6 & 1 & 7 & $13,5-17,0$ & $7(4)$ & 3 & 3 & 3 \\
\hline Pleuronectiformes & Paralichthyidae & Pseudorhombus & arsius & Largetooth flounder & 12 & 1 & 3 & 4 & $10,0-21,0$ & $4(0)$ & 3 & 3 & 2 \\
\hline Scorpaeniformes & Platycephalidae & Grammoplites & suppositus & Spotfin flathead & 13 & 0 & 1 & 1 & 30,5 & $1(1)$ & 1 & 1 & 1 \\
\hline Siluriformes & Ariidae & Netuma & thalassina & Giant catfish & 14 & 0 & 1 & 1 & 32,0 & $1(0)$ & 1 & 1 & 1 \\
\hline \multirow[t]{2}{*}{ Syngnathiformes } & Fistulariidae & Fistularia & petimba & Redcornet fish & 15 & 0 & 1 & 1 & 55,0 & $1(0)$ & 1 & 1 & 1 \\
\hline & & & & Total for all species & & 26 & 20 & 46 & - & $46(12)$ & 29 & 29 & 27 \\
\hline
\end{tabular}


Author-produced version of the article published in Regional Studies in Marine Science, 2017, 16, 145-151

The original publication is available at http://www.sciencedirect.com/

doi : 10.1016/j.rsma.2017.08.008

Table 2: Average stomach fullness (\%) and occurrence of various prey items ( $\%$ of fish with non-empty stomachs) in stomachs of fishes collected off Muscat coastal area in December 2013 and March 2014. Refer to number of individuals and fish size ranges. With NA: not available due to empty stomach (refer to Table 1 and text).

\begin{tabular}{|c|c|c|c|c|c|c|c|c|c|c|}
\hline \multirow{3}{*}{$\begin{array}{r}\text { Fish } \\
\text { species } \\
\text { (code) }\end{array}$} & \multirow{3}{*}{$\begin{array}{l}\text { Stomach } \\
\text { fullness }\end{array}$} & \multicolumn{5}{|c|}{ CRUSTACEANS } & \multirow{3}{*}{$\begin{array}{c}\text { MOLLUSCS } \\
\text { Gastropods }\end{array}$} & \multirow{3}{*}{$\begin{array}{l}\text { ANNELIDS } \\
\text { Polychaetes }\end{array}$} & \multirow{3}{*}{$\begin{array}{l}\text { TELEOSTEI } \\
\text { (bony fish } \\
\text { remains) }\end{array}$} & \multirow{3}{*}{$\begin{array}{c}\text { Particulate } \\
\text { Organic } \\
\text { Matter }\end{array}$} \\
\hline & & \multirow{2}{*}{ Unidentified } & \multicolumn{4}{|c|}{ Decapods } & & & & \\
\hline & & & Unidentified & Brachyura & Dendrobranchiata & Stomatopoda & & & & \\
\hline Saurida tumbil (1) & 95,0 & 0,0 & 0,0 & 0,0 & 25,0 & 0,0 & 0,0 & 0,0 & 100,0 & 0,0 \\
\hline Aetomylaeus nichofii (2) & 45,0 & 50,0 & 0,0 & 0,0 & 50,0 & 0,0 & 0,0 & 0,0 & 0,0 & 50,0 \\
\hline Taeniamia fucata (3) & 35,0 & 0,0 & 50,0 & 0,0 & 50,0 & 0,0 & 0,0 & 0,0 & 0,0 & 0,0 \\
\hline Ulua mentalis (4) & 30,0 & 0,0 & 0,0 & 0,0 & 100,0 & 0,0 & 0,0 & 0,0 & 100,0 & 0,0 \\
\hline Gerres filamentosus (5) & 13,3 & 33,3 & 33,3 & 0,0 & 0,0 & 0,0 & 0,0 & 0,0 & 0,0 & 66,7 \\
\hline Plectorhynchus pictus (6) & 30,0 & 0,0 & 0,0 & 100,0 & 100,0 & 0,0 & 100,0 & 0,0 & 0,0 & 100,0 \\
\hline Lutjanus lutjanus (7) & NA & NA & NA & NA & NA & NA & NA & NA & NA & NA \\
\hline Nemipterus bipunctatus (8) & 53,3 & 0,0 & 33,3 & 50,0 & 50,0 & 16,7 & 16,7 & 33,3 & 33,3 & 0,0 \\
\hline Nemipterus japonicas (9) & 46,7 & 0,0 & 0,0 & 66,7 & 100,0 & 0,0 & 33,3 & 0,0 & 0,0 & 33,3 \\
\hline Argyrops spinifer (10) & 26,7 & 0,0 & 0,0 & 100,0 & 66,7 & 0,0 & 33,3 & 0,0 & 0,0 & 0,0 \\
\hline Pelates quadrilineatus (11) & 38,4 & 0,0 & 0,0 & 0,0 & 66,7 & 0,0 & 0,0 & 0,0 & 33,3 & 33,3 \\
\hline Pseudorhombus arsius (12) & 26,3 & 0,0 & 25,0 & 50,0 & 25,0 & 0,0 & 0,0 & 0,0 & 0,0 & 0,0 \\
\hline Grammoplites suppositus (13) & NA & NA & NA & NA & NA & NA & NA & NA & NA & NA \\
\hline Arius thalassinus (14) & 5,0 & 0,0 & 0,0 & 100,0 & 0,0 & 0,0 & 0,0 & 0,0 & 0,0 & 0,0 \\
\hline Fistularia petimba (15) & 50,0 & 0,0 & 0,0 & 0,0 & 0,0 & 0,0 & 0,0 & 0,0 & 100,0 & 0,0 \\
\hline
\end{tabular}


Table 3: Mean and variance (var.) of $\delta^{13} \mathrm{C}, \delta^{15} \mathrm{~N}$ and $\delta^{34} \mathrm{~S}$ measured in fish muscle tissues in December 2013 and March 2014 in the Sea of Oman, all species combined. No significant differences were found between months for any isotopic ratio ( $P>0.05$ for all analyses).

\begin{tabular}{ccccccc} 
& \multicolumn{2}{c}{$\delta^{13} \mathrm{C}$} & \multicolumn{2}{c}{$\delta^{15} \mathrm{~N}$} & \multicolumn{2}{c}{$\delta^{34} \mathrm{~S}$} \\
\hline Month & Mean & Var. & Mean & Var. & Mean & Var. \\
\hline December & -15.94 & 0.96 & 16.03 & 0.24 & 17.13 & 3.84 \\
March & -15.90 & 0.33 & 15.72 & 0.72 & 16.57 & 3.68 \\
\hline
\end{tabular}

